\begin{tabular}{|l|l|l||}
\hline \multicolumn{2}{|c|}{ PublisherInfo } \\
\hline \hline PublisherName & $:$ & BioMed Central \\
\hline \hline PublisherLocation & $:$ & London \\
\hline \hline PublisherImprintName & $:$ & BioMed Central \\
\hline \hline
\end{tabular}

\title{
Multicenter Airway Research Collaboration
}

\begin{tabular}{||l|l|l||}
\hline \multicolumn{2}{|c|}{ ArticleInfo } \\
\hline \hline ArticleID & $:$ & 4287 \\
\hline \hline ArticleDOI & $:$ & $10.1186 /$ ccf-2000-webreport1583 \\
\hline \hline ArticleCitationID & $:$ & webreport1583 \\
\hline \hline ArticleSequenceNumber & $:$ & 28 \\
\hline \hline ArticleCategory & $:$ & Web report \\
\hline ArticleFirstPage & $:$ & 1 \\
\hline \hline ArticleLastPage & $:$ & 3 \\
\hline \hline & $:$ & RegistrationDate : 2000-4-7 \\
ArticleHistory & $:$ & OnlineDate $: 2000-4-7$ \\
\hline \hline ArticleCopyright & $:$ & Current Science Ltd2000 \\
\hline \hline ArticleGrants & $:$ & \\
\hline \hline ArticleContext & $:$ & 1305444 \\
\hline \hline
\end{tabular}


Aff1 Current Science Ltd, http://www.current-science.com/ltd/index.htmltarget=ne

\section{Background}

The Multicenter Airway Research Collaboration (MARC) was created by 12 emergency physicians in May 1996. The idea behind it was to form a network of emergency physicians with an interest in airway disorders, working together on large multicentre randomised clinical trials. This network specialised in setting up multicentre randomised trials with large enough patient groups to have enough statistical power to test the trial hypothesis. The MARC is currently carrying out over 10 trials looking at asthma, chronic obstructive pulmonary disease (COPD), and other airway disorders.

\section{Description}

This site contains information about all of the MARC trials. It provides summaries of the research protocols, including potential risks, purpose and procedures. All the North American institutions presently involved are listed by region, with contact details provided. The user can browse past newsletters (published three times a year). The newsletter keeps the reader 'informed of the progress of the present research efforts and their dissemination'. The reader can also view a list of all publications by the MARC. Any companies/institutions interested in getting involved with MARC can do so via this site.

\section{Other comments}

28th June 2000. The site appears to be updated at least twice weekly.

\section{Access requirements}

There are no access requirements for the main part of the site, which contains everything described above. There is a members area currently under construction. 


\section{References}

1. MARC. [http://healthcare.partners.org/marc/marc.htm]

This PDF file was created after publication. 